\title{
Magnesium and the Regulation of Germ-tube Formation in Candida albicans
}

\author{
By GRAEME M. WALKER, ${ }^{1 *}+$ PATRICK A. SULLIVAN ${ }^{1}$ AND \\ MAXWELL G. SHEPHERD ${ }^{2}$ \\ ${ }^{1}$ Department of Biochemistry, University of Otago, Dunedin, New Zealand \\ ${ }^{2}$ Experimental Oral Biology Unit, Faculty of Dentistry, University of Otago, Dunedin, \\ New Zealand
}

(Received 16 December 1983; revised 22 March 1984)

Candida albicans requires $\mathbf{M g}^{2+}$ for germ-tube formation. $\mathbf{M g - d e f i c i e n t ~ m e d i a , ~ m e t a l ~ i o n ~}$ chelators and the ionophore A23187 inhibited germ-tube formation. Cell $\mathbf{M g}$ content during exponential yeast-phase growth remained constant but increased throughout germ-tube formation. The onset of germ-tube formation coincided with a sharp peak in $\mathbf{M g}$ concentration within the cells. Yeast-phase cells of strain CA2, which did not form germ-tubes, had a lower $\mathbf{M g}$ content and failed to accumulate $\mathrm{Mg}$ when incubated under conditions for germ-tube formation. $\mathrm{Mg}$ also increased the uptake and incorporation of $\mathrm{N}$-acetylglucosamine. These findings point to a central regulatory role for $\mathrm{Mg}$ in $\mathrm{C}$. albicans morphogenesis.

\section{INTRODUCTION}

Candida albicans, the causative agent of mycotic infections collectively known as candidosis, is a convenient organism for studying the regulation of differentiation. It is dimorphic and grows either by forming buds (as in most laboratory media) or by elongating as hyphae (Odds, 1979). The induction of germ-tube formation in C. albicans is the initial stage in the yeast-to-mycelial transition (Cassone et al., 1973), and a number of environmental factors have been described which effect this transition (Odds, 1979). Previous studies have pointed indirectly to the involyement of magnesium ions in C. albicans morphogenesis (Widra, 1964; Simonetti et al., 1974; Gooday, 1978), but this study represents the first attempt to identify a regulatory role for magnesium in the initiation of germ-tube formation in this organism.

\section{METHODS}

Organisms and culture conditions. The strains of $C$. albicans used in this study were ATCC 10261, A72 and CA2. Strains A72 and CA2 were provided by Dr A. Cassone, Instituto Superiore di Sanito, Rome, Italy. A72 has been designated a 'high-responder' with respect to germ-tube formation and CA2 a non-germ-tube former (Mattia et al., 1982). Conditions for propagation of the organism have been described previously (Shepherd \& Sullivan, 1976), Cell numbers (the mean of 4 counts of $\sim 100$ cells) were determined using a haemocytometer. Yeast cells were scored as two when the daughter bud had reached two-thirds the size of the mother cell.

Germ-tube induction. The pH shift method of Lee et al. (1975) and the $N$-acetylglucosamine (GlcNAc) induction system of Simonetti et al. (1974) were used to induce formation of germ-tubes in C. albicans. Both methods require a temperature of $37^{\circ} \mathrm{C}$. With strain A72, the starvation/aeration pretreatment used by Shepherd et al. (1980) was not deemed necessary to produce a high proportion of germ-tubes in the GlcNAc induction system. The percentage of germinating cells was routinely assessed using a haemocytometer.

Incorporation of $N$-acetylglucosamine. $N$-Acetyl-D $\left[1-{ }^{14}\right.$ Clglucosamine $[0.05 \mu \mathrm{Ci}(1.85 \mathrm{kBq}) ; 0.2 \mu \mathrm{mol}$; Amersham] was added $(50 \mu \mathrm{l})$ to yeast cultures $(50 \mathrm{ml})$ and duplicate $1 \mathrm{ml}$ samples were removed periodically. Each sample was washed on a Whatman GF/C glass-fibre filter three times with distilled water and twice with ethanol.

† Present address: School of Biological Sciences, National Institute for Higher Education, Dublin 9, Ireland.

Abbreviation: GlcNAc, $N$-acetylglucosamine. 
The filters were placed in vials containing Triton/toluene scintillant and radioactivity was determined in an LKB 1215 Rackbeta II liquid scintillation counter.

Magnesium analysis. Cell magnesium content was determined by flameless atomic absorption spectrophotometry (Walker \& Duffus, 1980) after microcentrifuging cells through silicon oil of appropriate specific gravity (Walker \& Zeuthen, 1980).

Chemicals. Concentrated stock solutions of EDTA, EGTA and sodium pyrophosphate were prepared by dissolving the chemicals in water and adjusting the $\mathrm{pH}$ to 6.6. Concentrated stock solutions of the ionophore A23187 (from Calbiochem) were prepared by dissolving it in acetone and ethanol. Appropriate quantities of these stock reagents were added directly to cultures to give the final desired concentration. $\mathbf{M g}, \mathrm{Mn}, \mathrm{Ca}$ and $\mathrm{Zn}$ were added directly as their chloride salts to give the final desired concentrations. All solutions were prepared in water which had been distilled and further purified by passage through a Milli-Q system (Millipore).

\section{RESULTS AND DISCUSSION}

If stationary-phase cells of $C$. albicans were inoculated in an amino acid-rich medium at $\mathrm{pH} 7.3$ and at $37^{\circ} \mathrm{C}$ (Lee et al., 1975), they synchronously formed germ-tubes (see also Mitchell $\&$ Soll, 1979). However, such cells failed to germinate if they were inoculated into $\mathrm{Mg}$-free media (data not shown). Similarly, cells failed to germinate in the GlcNAc induction system made deficient in $\mathbf{M g}^{2+}$ (Fig. 1). The buffer system normally uses $\mathbf{M n}^{2+}$ (Simonetti et al., 1974), but we consistently found that if $\mathbf{M n}^{2+}$ was replaced by $\mathbf{M g}^{2+}$, a significantly higher percentage of germ-tubes was obtained (Fig. 1). We also found that the proportion of germ-tubes obtained in Mn-containing buffer was dependent on the concentration of contaminating $\mathbf{M g}^{2+}$ (data not shown). $\mathrm{Ca}^{2+}$ and $\mathrm{Zn}^{2+}$ failed to substitute for $\mathbf{M g}^{2+}$ in producing a high percentage of germ tubes (Fig. 1).

The dependence of germ-tube formation on $\mathrm{Mg}^{2+}$ concentration was confirmed (Fig. 2) by inhibiting germination with agents known to affect $\mathbf{M g}^{2+}$ availability, such as the chelators EDTA and sodium pyrophosphate and the ionophore A23187. EGTA, a chelator with a greater affinity for $\mathrm{Ca}^{2+}$ than $\mathrm{Mg}^{2-}$, failed to produce the same inhibiting effects as $\mathrm{Mg}^{2+}$ chelators.

Figure 3 shows the concentration of cell- $\mathrm{Mg}$ in cultures of $C$. albicans 10261 which were induced to grow either by yeast-phase budding or by germ-tube elongation. The different modes of development were established by manipulating the $\mathrm{pH}$ of the medium (Lee et al., 1975; Mitchell \& Soll, 1979). The cell $\mathrm{Mg}$ content remained constant during exponential growth of yeast-phase cultures ( $\mathrm{pH} 4.5$ ), whereas during germ-tube formation the $\mathrm{Mg}$ content per cell doubled over the $4 \mathrm{~h}$ incubation period. If $\mathrm{Mg}$ values were to be expressed on a dry weight basis, cell $\mathrm{Mg}$ would remain relatively constant since the dry weight of $C$. albicans mass increases by $100 \%$ over this period (Shepherd et al., 1980). However, the gradual increase was interrupted by a peak of $\mathrm{Mg}$ content per cell which coincided with the onset of germ-tube formation. This peak represents a three-fold increase indicating a transient, but net, increase in cell $\mathrm{Mg}$ at this time. We have observed similar qualitative changes in cell $\mathbf{M g}$ (including a $\mathrm{Mg}$ peak) in cultures induced for germ-tube formation in the GlcNAc system (data not shown). This Mg influx may represent a controlling element in yeast-to-mycelial transition in $C$. albicans, perhaps by activating enzymes for chitin synthesis or by governing chitin deposition. Both processes are required for mycelial cell wall extension. With regard to chitin synthesis, it is of interest that the specific activity of chitin synthase increases three-fold during the initial period of germ-tube formation (Chiew et al., 1980) and this enzyme is Mg-dependent. Gooday (1978) has previously suggested that $\mathrm{Mg}$ may play an in vivo role in regulating this key enzyme in $C$. albicans. With regard to chitin deposition, it is likely that cytoplasmic microtubules are involved in this process since these organelles are known to govern cell wall extension in fungi (Howard \& Aist, 1980). Walker \& Duffus (1983) have recently proposed that $\mathrm{Mg}$ controls the integrity of microtubules in vivo; $\mathrm{Mg}$ may, therefore, affect $C$. albicans morphology at the level of the cytoskeleton.

Strains A72 and CA2 are distinguished by their differing capabilities to form germ-tubes: A72 has been designated a 'high-responder' and CA2 a non-germ-tube former (Mattia et al., 1982). In an effort to determine if these strains also differed in their cell $\mathrm{Mg}$ status and in their ability to take up $\mathrm{Mg}^{2+}$, both strains were incubated at $37^{\circ} \mathrm{C}$ in buffered GlcNAc and the percentage germ-tubes and cell $\mathrm{Mg}$ were monitored over $4 \mathrm{~h}$. With strain CA2 the $\mathrm{Mg}$ content remained 


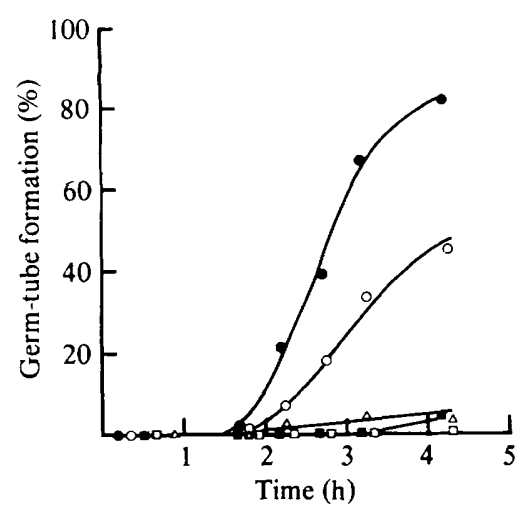

Fig. 1

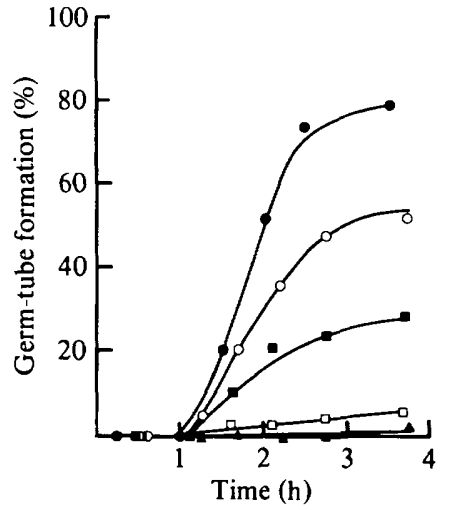

Fig. 2

Fig. 1. Influence of divalent metal cations on germ-tube formation in C. albicans A72. Cells were propagated for $18 \mathrm{~h}$ in a glucose/salts/biotin medium (Mitchell \& Soll, 1979), harvested, washed and resuspended to $10^{8}$ cells $\mathrm{ml}^{-1}$ in glass-distilled water. Samples of these suspensions were added to buffered GlcNAc (Shepherd et al., 1980), but minus the Mn source, and incubated with shaking at $37^{\circ} \mathrm{C}$. Appropriate divalent metal cations were added to the buffer system to give final concentrations of $0.5 \mathrm{~mm}$. $\square$, Control (no ions added);, $\mathrm{Mg} ; \mathrm{O}, \mathrm{Mn} ; \triangle, \mathrm{Ca} ; \square, \mathrm{Zn}$.

Fig. 2. Inhibition of germ-tube formation in C. albicans A72 by chelating agents and the ionophore A23187. Cells were prepared as for Fig. 1 and incubated in buffered GlcNAc plus $0.5 \mathrm{mM}-\mathrm{Mg}^{2+}$ with chelating agents at final concentrations of $40 \mathrm{mM}$. The final concentration of the ionophore A23187 was $10 \mu \mathrm{g} \mathrm{ml}^{-1} .0$, Control (no additions); O, EGTA: $\square$, sodium pyrophosphate; $\square$, EDTA; $\mathbf{A}$, A23187.

constant ( $16 \pm 1.5 \mathrm{fg}$ per cell) whereas with strain A72 the initial $\mathrm{Mg}$ content was $36 \mathrm{fg}$ per cell which increased steadily (with no detectable $\mathrm{Mg}$ peak) to $80 \mathrm{fg}$ per cell during germ-tube formation. These findings clearly indicate that $C$. albicans mutants which are defective in germtube formation also possess altered capacities to accumulate $\mathrm{Mg}^{2+}$.

Widra (1964) has previously shown that yeast or mycelial forms of C. albicans can be induced by manipulating the phosphate supply in the growth medium. This was interpreted by Widra (1964) on the basis of the binding of $\mathrm{Mg}^{2+}$ by polyphosphate within the cell. Thus, in high phosphate conditions, excess polyphosphate forms to bind high levels of $\mathbf{M g}^{2+}$ which results in production of mycelial forms. Conversely, in low phosphate conditions, $\mathrm{Mg}^{2+}$ remains unbound and this results in production of yeast forms. In the present work, we can only speculate whether changes in free $\mathbf{M g}^{2+}$ govern yeast-to-mycelial transitions because our measurements of total cell $\mathrm{Mg}$ give no indication of the proportion of free and bound $\mathrm{Mg}$ within the cell. Consequently, we are unable to support or refute the postulate put forward by Widra (1964).

$\mathrm{Mg}$ enhanced the incorporation of $\left[{ }^{14} \mathrm{C}\right] \mathrm{GlcNAc}$ into yeast cells incubated at $28^{\circ} \mathrm{C}$ for $2 \mathrm{~h}$ (Fig. 4). When the Mg-supplemented and $\mathrm{Mg}$-deprived cultures were transferred to $37^{\circ} \mathrm{C}$, GlcNAc uptake continued initially at the same rates, but only the former produced germ-tubes. The rates of incorporation decreased with continued incubation because the exogenous GlcNAc became depleted (Sullivan et al., 1983). The ionophore A23187 immediately inhibited germ-tube formation and GlcNAc incorporation in the $\mathrm{Mg}^{2+}$-supplemented culture (Fig. 4). In further experiments in which $\mathrm{Mg}$-deprived cells were induced for GlcNAc uptake at $28^{\circ} \mathrm{C}(2 \mathrm{~h})$, as described in Fig. 4, the addition of $\mathrm{Mg}^{2+}$ after the transfer to $37^{\circ} \mathrm{C}$ increased the rate of GlcNAc uptake and triggered germ-tube formation. Direct measurement of GlcNAc uptake rates (Sullivan \& Shepherd, 1982) after $4 \mathrm{~h}$ incubation at $28^{\circ} \mathrm{C}$ gave values of 40 and $60 \mathrm{nmol}$ $\min ^{-1}$ (mg dry wt) ${ }^{-1}$ for the $\mathrm{Mg}$-deprived and $\mathrm{Mg}$-supplemented cells, respectively. In support of the role proposed above for $\mathrm{Mg}^{2+}$ in regulating chitin synthesis and deposition, these data demonstrate a direct link between the incorporation of $N$-acetylglucosamine (which activates chitin synthase) and $\mathbf{M g}^{2+}$ availability.

In conclusion, we propose that $\mathrm{Mg}^{2+}$ plays a central role in regulating dimorphism in $C$. albicans through a combination of its effects on enzyme activation and cytoskeletal organization. 

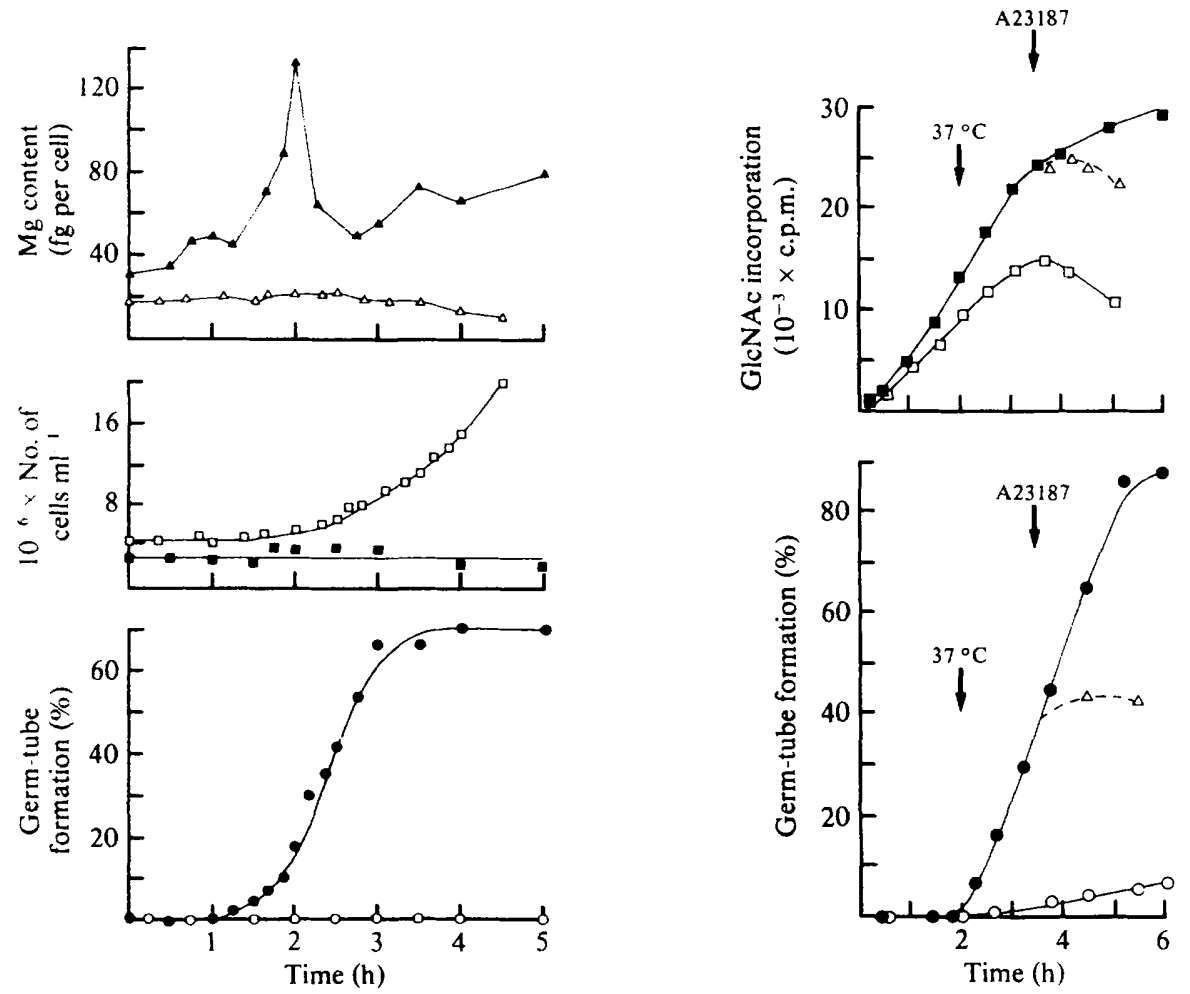

Fig. 3

Fig. 4

Fig. 3. Changes in cell magnesium content during yeast growth and germ-tube formation of $C$. albicans 10261. Cells were cultivated in an amino acid-rich medium (Lee et al., 1975) and induced to grow either by yeast-phase budding at $\mathrm{pH} 4.5$ (open symbols) or by forming germ-tubes at $\mathrm{pH} 7 \cdot 3$ (filled symbols).

Fig. 4. Influence of magnesium on germ-tube formation and GlcNAc incorporation. Yeast cells of $C$. albicans A72 were prepared as for Fig. 1 and resuspended in buffered GlcNAc containing $N$-acetyl-D-[1${ }^{14} \mathrm{Clglucosamine}$ with or without $\mathrm{Mg}^{2+}$. After $2 \mathrm{~h}$ incubation at $28^{\circ} \mathrm{C}$, the cultures were shifted to $37^{\circ} \mathrm{C}$. In one experiment the ionophore A23187 $\left(10 \mu \mathrm{g} \mathrm{m}^{-1}\right)$ was added to the $\mathrm{Mg}$-supplemented culture: $\square$, with $\mathbf{M g} ; \square, O$, without $\mathbf{M g} ; \triangle$, with the ionophore $\mathbf{A} 23187$.

This work, undertaken while G. M. W. was a Visiting Lecturer in Biochemistry at Otago, was supported by grants from the Medical Research Council of New Zealand. We thank Mr J. Dunckley of Dunedin Hospital for provision of the atomic absorption spectrophotometer.

\section{REFER ENCES}

Cassone, A., Simonetti, N. \& Strippoli, V. (1973). Ultrastructural changes in the wall during germ-tube formation from blastospores of Candida albicans. Journal of General Microbiology 77, 417-426.

Chiew, Y. Y., Shepherd, M. G. \& Sullivan, P. A. (1980). Regulation of chitin synthesis during germtube formation in Candida albicans. Archives of Microbiology 125, 97-104.

GoODAY, G. (1978). The enzymology of hyphal growth. In The Filamentous Fungi, vol. 3, pp. 51-57. Edited by J. E. Smith \& D. R. Berry. London: Edward Arnold.

Howard, R. J. \& AIST, J. R. (1980). Cytoplasmic microtubules and fungal morphogenesis: ultrastructural effects of methyl benzimidazole-2-yl carbamate determined by freeze substitution of hyphal tips. Journal of Cell Biology, 87, 55-64.
LeE, K. L., BuCKLey, H. R. \& CAMpbell, C. C. (1975). An amino acid liquid synthetic medium for development of mycelial and yeast forms of Candida albicans. Sabouraudia 13, 148-153.

Mattia, E., Carruba, G., Anglolella, L. \& CasSONE, A. (1982). Induction of germ-tube formation by $\mathrm{N}$-acetylglucosamine in Candida albicans. Uptake of inducer and germinative responsive. Journal of Bacteriology 152, 555-562.

Mitchell, L. H. \& Soll, D. R. (1979). Commitment to germ-tube or bud formation during release from stationary phase in Candida albicans. Experimental Cell Research 120, 167-169.

ODDS, F. C. (1979). Morphogenesis in Candida with special reference to $C$. albicans. In Candida and Candidosis, pp. 29-41. Edited by F. C. Odds. Leicester: Leicester Univerity Press. 
Shepherd, M. G. \& Sullivan, P. A. (1976). The production and growth characteristics of yeast and mycelial forms of Candida albicans in continuous culture. Journal of General Microbiology 93, 361370.

Shepherd, M. G., Chiew, Y. Y., RaM, S. P. \& Sullivan, P. A. (1980). Germ-tube induction in Candida albicans. Canadian Journal of Microbiology 26, 21-26.

Simonetti, N., Strippoli, V. \& Cassone, A. (1974). Yeast-mycelial conversion induced by $N$-acetyl-Dglucosamine in Candida albicans. Nature, London 250, 344-346.

Sullivan, P. A. \& Shepherd, M. G. (1982). Gratuitous induction by $\mathrm{N}$-acetylmannosamine of germtube formation and enzymes for $N$-acetylglucosamine utilisation in Candida albicans. Journal of Bacteriology 151, 1118-1122.
Sullivan, P. A., Chiew, Y. Y., Molloy, C., TempleTON, M. D. \& SHEPHERD, M. G. (1983). An analysis of the metabolism and cell wall composition of Candida albicans during germ-tube formation. Canadian Journal of Microbiology 29, 1514-1525.

W ALKer, G. M. \& Duffus, J. H. (1980). Magnesium ions and the control of the cell cycle in yeast. Journal of Cell Science 42, 329-356.

WALKER, G. M. \& DUfFus, J. H. (1983). Magnesium as the fundamental regulator of the cell cycle. Magnesium 2, 1-16.

WalKer, G. M. \& Zeuthen, E. (1980). Changes in calcium and magnesium levels during heat shock synchronized cell division in Tetrahymena. Experimental Cell Research 127, 487-490.

WIDRA, A. (1964). Phosphate directed Y-M variation in Candida albicans. Mycopathologia et mycologia applicata 23, 197-202. 